\title{
Immune-serological identification of infectious agents with influence on bovine embryo transfer in the north of Brazil
}

\author{
Identificación inmunoserológica de agentes infecciosos con influencia \\ sobre la transferencia de embriones en el norte de Brasil

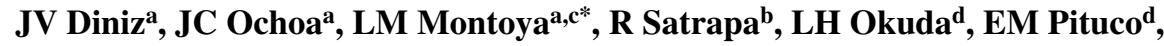 RR Marcelino ${ }^{\mathrm{b}}, \mathbf{E}_{\mathbf{O b a}^{\mathrm{a}}}$

\begin{abstract}
The aim of this study was to investigate antibodies against brucellosis, leptospirosis, bovine rhinotracheitis (IBR/ BoHV-1), bovine viral diarrhea (BVD) and neosporosis through immunodiagnostic. These agents may directly or indirectly compromise the female bovine reproductive tract as well as embryonic and fetal development, therefore we also tried to establish a probable relation between those antibody with the utilization rates of fixed-time embryo transfer (FTET) protocols, with pregnancy rate per embryo transfer (ET) and the occurrence of miscarriages. Embryos were obtained by in vitro fertilization of the ovum and sperm from the Gyr dairy breed, which were transferred to 235 zebu-crossbred cows under FTET protocols. The blood samples to obtain serum were collected by venous puncture from coccygeal vein, only a few days of the completion of ET. For the immunodiagnostic research of brucellosis, leptospirosis, IBR/BoHV-1, BVD and neosporosis, the complement fixation assay, the microscopic agglutination test, virus neutralization, and linked immunosorbent assay to enzymes in conjunction with the indirect immunofluorescence were used. The utilization rates of the FTET protocols related to pregnancy and abortion in D16, D35, and D75 were 67.23\%, 34,18\% and 20,37\% respectively. The immunodiagnostic results related to seropositive animals were obtained for brucellosis $(7 / 235=2.89 \%)$, leptospirosis $(128 / 235=54.47 \%)$, IBR $(103 / 235=43.83 \%)$, BVD $(174 / 235=74.04 \%)$, and neosporosis $(150 / 235=63.82 \%)$. In seropositive recipients, there was an observed influence $(\mathrm{P}<0.05)$ of leptospirosis and neosporosis on the rate of protocol utilization of brucellosis on both the pregnancy and abortion rate, and of BVD and IBR on abortion rate.

Key words: reproductive, embryo, recipients, cattle.
\end{abstract}

RESUMEN. El estudio tuvo por finalidad evidenciar, mediante técnicas de inmunodiagnóstico, anticuerpos contra Brucelosis, Leptospirosis, Rinotraqueítis Infecciosa Bovina (IBR), Diarrea Viral Bovina (DVB) y Neosporosis, agentes que directa o indirectamente pueden comprometer el tracto reproductor de las hembras así como el desarrollo embrionario y fetal. Se estableció una probable relación entre la presencia de anticuerpos contra los agentes con la tasa de aprovechamiento de protocolos de transferencias de embriones en tiempo fijo (TETF), la tasa de preñez por transferencia de embriones (TE) y la ocurrencia de abortos. Los embriones fueron obtenidos por fertilización in vitro (FIV) a partir de aspiración folicular y semen de toros, ambos de raza Gyr lechero, y tranferidos a 235 vacas receptoras cruzadas con Cebú sometidas a protocolos para TETF. Se obtuvo suero de muestras de sangre mediante venopunción de la vena coccígea solamente en los días de realización de TE. Para evidenciar Brucelosis, Leptospirosis, IBR, DVB y Neospora se emplearon las técnicas de fijación de complemento, seroaglutinación microscópica, seroneutralización y test de inmunoensayo (ELISA) junto con la inmunofluorescencia indirecta (RIFI), respectivamente. El diagnóstico de gestación de las receptoras fue efectuado por ultrasonografía, a los 35 días despúes de la TE y repetido a los 75 días para confirmar la gestación o eventual aborto. Los animales serorreactivos para cada agente fueron: Brucella $(7 / 235=2,89 \%)$, Leptospirosis $(128 / 235=54,47 \%)$, IBR $(98 / 235=43,83 \%)$, DVB $(174 / 235=74,04 \%)$ y Neosporosis $(150 / 235=63,82 \%)$. En las receptoras serorreactivas se observaron influencias $(\mathrm{P}<0,05)$ de la leptospirosis y de la neosporosis sobre la tasa de aprovechamiento del protocolo, de brucelosis en las tasas de preñez y aborto y en DVB e IBR en las tasas de aborto.

Palabras clave: reproductivo, embrión, receptor, ganado.

\section{INTRODUCTION}

The control of infectious diseases is inextricably linked to the ability of diagnostic tests to define the exposure of

Accepted: 08.10.2015.

${ }^{a}$ Faculdade de Medicina Veterinária e Zootecnia, Universidade Estadual Paulista, Campus de Botucatu,Brazil.

${ }^{\mathrm{b}}$ Centro para o Melhoramento da Genética Animal do Estado de Acre, Rio Branco, Brazil.

${ }^{\mathrm{c}}$ Grupo de Pesquisa en Patologia Veterinaria, Faculdad de Ciencias Agrárias, Universidad de Caldas, Manizales, Colombia.

${ }^{\mathrm{d} C e n t r o ~ d e ~ S a u ́ d e ~ A n i m a l, ~ I n s t i t u t o ~ B i o l o ́ g i c o ~ d e ~ S a ̃ o ~ P a u l o, ~ S a ̃ o ~ P a u l o, ~}$ SP, Brazil.

*Corresponding author: LM Montoya; Distrito de Rubião Junior s/n, Botucatu, SP 18618-970, Brazil; maomontoya53 @yahoo.es a population or individual to the agent in question. In fact, control can be performed simply on the basis of laboratory testing and animal management (Duvobi 2013). In cattle, several factors can interfere in reproductive performance, among which are those related to the pathophysiology of the reproductive system, genetics, nutrition and health management of livestock herds (Corrêa et al 2000, Royal and Flint 2000, Sayers et al 2015). Herd health, in particular, infections that directly or indirectly compromise the reproductive tract of the female and male and the viability of the embryo and fetus, are the main factors affecting reproductive efficiency of cattle (Vanroose and Van 2000, Okano et al 2003, Takiuchi et al 2005).

Diseases of breeding animals such as brucellosis, leptospirosis, infectious bovine rhinotracheitis (IBR/ 
BoHV-1), bovine viral diarrhea (BVD) and neosporosis are disseminated in the national herd (Del Fava et al 2007). Allegedly, leptospirosis, IBR/BoHV-1, BVD and neosporosis are also occurring in the Acre state in north of Brazil. However, health authorities or research institutions have not identified them and eventual eradication of these diseases has been defined as an objective to reduce the economic losses in this cattle population.

In order to attribute some miscarriage or repeat-breeder cow cases to these diseases, their effective identification is necessary. Therefore, developing an appropriate prophylactic plan aimed at animal health would be the next step. Furthermore, the confirmation of their presence is important, because some are zoonoses (Seleem and Boyle 2010, Adler et al 2011, Desvars and Michault 2011) and are listed as notifiable diseases by the Office International Epizooitic (OIE).

Simultaneously, the use of ET seeks to raise the genetic standard of dairy cattle to reduce the number of animals with low production in the region. This will gradually increase the productivity and production of new animals with superior genetics. In the end, the pressure of deforestation on forest measures will eventually be decreased, converging to the concept of sustainable development in the region.

The State of Acre has currently developed a program of breeding dairy cattle embryos by granting good lineage to small dairy farmers, under the responsibility of the Station Improvement and Dissemination of Animal Genetics (EMDGA), an agency of the State Department of Agriculture (SEAP). Because of this program, frequent technical visits to the properties were made, which greatly facilitates the permission of such owners to investigate the possible occurrence of the aforementioned diseases.

This work aims to present the results of serological surveys for studied diseases and to analyze to what extent the seropositive embryo recipients had reproductive parameters affected by these conditions.

\section{MATERIAL AND METHODS}

This study was approved by the Ethics Committee on Animal Experimentation of the Veterinarian Medicine Faculty, UNESP-Botucatu, São Paulo, Brazil, which is consistent with the ethical principles in animal experimentation. Two hundred and thirty-five non-lactating uni or multiparous crossbred cows (Bos taurus $x$ Bos taurus indicus) were used as embryo recipients. Animals were raised on pasture, water and mineral salt were provided ad libitum, and body condition score between 3 and 4 on a scale 1-5 (Ferreira y Torres 1993). They belonged to 11 properties, distributed in six counties of the State of Acre (Latitude: 09' 58 '29' and longitude: 67'48'36”).

All recipients were subjected to the same protocol of induction/synchronization of estrus for FTET in batches of 10 to 12 animals. All cows were examined by rectal palpation before synchronization. Non-pregnant cows with or without corpus luteum were chosen as suitable recipients for synchronization. All groups of recipients underwent, on different dates, the same protocol on a random day of the estrous cycle, as follows: (D0), each recipient received 1 $\mathrm{g}$ of $\mathrm{P} 4$ through releasing intravaginal device and $2.5 \mathrm{mg}$ of estradiol benzoate (BE) intramuscularly (IM). On D8, the $\mathrm{P} 4$ device was removed and $\mathrm{D}-150 \mu \mathrm{g}$ D-cloprostenol (PGF2), 400 IU of equine chorionic gonadotropin (eCG), and $1 \mathrm{mg}$ of BE, IM, were administered. On D16, each recipient received a transferred embryo (blastocyst, grade 1 or 2) at FTET, after ultrasound diagnosis (Aloka SSD 500, Aloka, Japan) of a corpus luteum (CL) and its location in an ovary.

Embryos were produced by in vitro fertilization (FIV) with oocytes obtained by follicular aspiration from donors belonging to EMDGA, in whose laboratory all procedures were performed. The donor and the semen of bulls used for FIV are Gyr dairy breed. The recipients that showed CL were considered as utilized according to hormonal synchronization protocols. Pregnancy diagnosis was performed by ultrasonography (US) on D35 and repeated on D75 for occurence of abortion.

Immunodiagnostic surveys were conducted on the day of embryo transfer (D16). Sixteen days after the start of the protocol for FTET, blood samples were collected by venous puncture from the coccygeal vein. To obtain serum, vacuum tubes without anticoagulant, with gel separator, were used and maintained at room temperature in an inclined position. Next, tubes were centrifuged at $900 \mathrm{G}$ for 10 minutes with lid to prevent evaporation, formation of aerosols and to avoid contamination risk of samples. Samples were then marked according to animal identification number. The serum obtained was fractionated into two $1.5 \mathrm{ml}$ microtubes and stored at $-20{ }^{\circ} \mathrm{C}$. Aliquots were packed in coolers with ice before being sent to the Biological Institute of St. Paulo, Brazil, for testing.

For diagnosis of brucellosis and leptospirosis, samples were sent to the R \& D Center of Animal Health, Laboratory of Bacterial Reproduction of the Biological Institute of São Paulo. Specific diagnosis of brucellosis (Brucella abortus) utilized a complement fixation technique, taking as reference reagents $\geq 20 \mathrm{UI}$, which was recommended by the National Plan for the Eradication of Brucellosis (Brazil 2006). For Leptospirosis, serum samples were processed by different laboratory exams, taking into account the pathogen, and the most effective method of its diagnosis. In this case, the microscopic agglutination test (MAT) in the presence of at least 18 serovars of leptospirosis grown in the laboratory was utilized, as recommended by Faine et al (1999). Regarded as the sample reagent, they had agglutination of at least $50 \%$ at a 1:100 dilution. The reagent samples were titrated in increasing dilutions, according to the technique recommended by the National Health Foundation (Brazil $1995)$, taking as reference reagents $\geq 1: 100$.

For antibodies against IBR/BoHV-1 and BVD, samples were also sent to Bovine Viruses Laboratory, Animal 
Health Research Center, Biological Institute of São Paulo, and analyzed by virus neutralization technique. Titer of 2 or less to IBR/BoHV-1 and 10 for BVD, were adopted as cutoffs to consider samples as nonreactive. For serological diagnosis of neosporosis, immunoassay tests (ELISA) were performed in all synchronized animals, and indirect immunofluorescence assays (IFA) in animals that aborted.

\section{STATISTICAL ANALYSIS}

To study the relations between seropositive diseases described by the utilization rates of FTET protocols, for pregnancy and abortion, a Chi-Square test was used, at a significance level of 5\% (P < 0.05) (Magalhães and Lima 2000).

\section{RESULTS}

The utilization rates of the FTET protocols at D16, and for pregnancy and abortion proportions at D35, and D75 were $67.23 \%$ (158/235), $34.18 \%$ (54/158) and $20.37 \%$ (11/54), respectively.

Table 1 shows frequency of reagent recipients to immunodiagnostic tests for investigated diseases. High percentages of leptospirosis, IBR, BVD and neosporosis seroconversion were observed. However, for brucellosis, a low seroconversion exists mainly due to working criteria required by EMDGA. It means that all researched recipients must necessarily undergo to presort, which may explain the lower frequency of seroreactivity when compared to other diseases not submitted to the aforementioned procedure.

When matched with the results of simultaneous immunodiagnostic occurrence of seroreactivity, recipient cases with 5 diseases were not observed. On the contrary, a higher rate was present in recipients with two and three diseases (table 2). Analyzing the results of 11 abortions, five of them $(5 / 11=45.45 \%)$ were serum positive to 3 concurrent diseases, $4(4 / 11=36.36 \%)$ to 4 diseases, 1 $(1 / 11=9.09 \%)$ to 2 diseases, and $1(1 / 11=9,09 \%)$ to 1 disease.

The number of "seropositive" and "nonreactive" recipients of the studied diseases was distributed according to the reproductive activity previously proposed in the study. Among the 11 aborting recipients, $2(2 / 11=18.18 \%)$ were positive for brucellosis, presenting a titration of 640UI for each recipient. It was noted that pregnancy rates and abortion showed different frequencies, which indicates a dependency to receptor seropositivity at the presence of Brucella abortus $(\mathrm{P}<0.05)$ (table 3$)$.

For leptospirosis, 3 animals $(3 / 11=27.27 \%)$ resulted positively to the following serovars (accompanied by titration value), as follows: the first animal, L. icterohaemorrhagiae (200), L. wolffi (200) and L. hardjo (400), the second, $L$. wolffi (400) and $L$. hardjo (400); and the last, $L$. wolffi (1600) and $L$. hardjo (1600). After statistical testing, the utilization rates of FTET protocols showed dependent
Table 1. Frequency of embryo recipients, depending on the nature of the immunodiagnostic results.

Frecuencia de receptores de embriones, según la naturaleza de los resultados imunodiagnósticos.

\begin{tabular}{lcc}
\hline Diseases & Reagents & Non reagents \\
\hline Brucellosis & $7(2.98 \%)$ & $228(97.03 \%)$ \\
Leptospirosis & $128(54.47 \%)$ & $107(45.53 \%)$ \\
IBR & $103(43.83 \%)$ & $132(56.17 \%)$ \\
BVD & $174(74.04 \%)$ & $61(25.96 \%)$ \\
Neosporosis & $150(63.83 \%)$ & $85(36.17 \%)$ \\
\hline
\end{tabular}

Absolute values and percentages.

Table 2. Distribution of the immunodiagnostic results for simultaneous occurrence of diseases.

Distribución de resultados inmunodiagnósticos para ocurrencia simultánea de enfermedades.

\begin{tabular}{lc}
\hline Diseases receptor & Reagents $(\%)$ \\
\hline No case & $5(2.13 \%)$ \\
One & $47(20 \%)$ \\
Two & $85(36.17 \%)$ \\
Three & $78(33.19 \%)$ \\
Four & $20(8.5 \%)$ \\
\hline
\end{tabular}

Absolute values and percentages.

variables. Therefore, the response to hormonal protocol is linked to whether or not the recipient is reagent to the presence of leptospira serovars $(\mathrm{P}<0.05)$ (table 4$)$.

A high number of seroreactive recipients with high titer for qualitative tests of IBR and BVD were found. In the case of BVD, $138(138 / 174=79.31 \%)$, and $91(91 / 103=$ $88.35 \%$ ) in the case of IBR, were positive. This indicates a high viral load. Allegedly, this outcome could be the cause for IBR abortion (tables 5 and 6).

Regarding abortions related to BVD, there were nine $(81.82 \%)$ reagent recipients that had a titration, after the qualitative test for virus neutralization, in the following proportions: 2,560 (11.11\%), 1,280 (22.22\%), 320 (11, $11 \%), 80(22.22 \%) 40(11.11 \%)$ and $10(22.22 \%)$. In the case of IBR, there were 8 aborting recipients $(72.73 \%)$, with qualitative test bonded by virus neutralization, comparing to BoHV-1, were 1024 (25\%), 512 (25\%), 256 (37.5\%) and $128(12.5 \%)$. When performing a statistical test to evaluate the rate of abortion, it was observed that variables were dependent. Therefore, the abortions occurred depending on the recipient seropositivity at the presence of at least one species of virus $(\mathrm{P}<0.05)$.

Five aborting recipients $(5 / 11=45.45 \%)$ were positive to neosporosis in ELISA, and to indirect immunofluorescence, with titers above 400 . Among them, a titer of 3200 appeared which is considered high and suggestive of an active infection. The high antibody titers in cows with titer equal to 3200 may be associated with reactivation 
DINIZ ET AL

Table 3. Frequency of embryo recipients positive for Brucellosis and its relation to reproductive activity.

Frecuencia de receptores de embriones positivos para Brucellosis y su relación con la actividad reproductiva.

\begin{tabular}{lccc}
\hline \multirow{2}{*}{ Activities } & \multicolumn{2}{c}{ Brucellosis } & \multirow{2}{*}{ Total animals } \\
\cline { 2 - 4 } & Reagents & Non reagents & 235 \\
\hline Synchronized & $7(2.98 \%)$ & $228(97.02 \%)$ & 158 \\
FTET & $3(1.90 \%)$ & $155(98.10 \%)$ & 77 \\
Protocols rejected $*$ & $4(5.20 \%)$ & $73(94.80 \%)$ & 54 \\
Pregnancy rate & $3(5.56 \%)^{* *}$ & $51(94.44 \%)$ & 11 \\
Abortion rate & $2(18.18 \%)^{* *}$ & $9(81.82 \%)$ & \\
\hline
\end{tabular}

$*$ Absence of $\mathrm{CL}, * * \mathrm{P}<0.05$.

Table 4. Frequency of embryo recipients positive for Leptospirosis and its relation to reproductive activity.

Frecuencia de receptores de embriones positivos para Leptospirosis y su relación con la actividad reproductiva.

\begin{tabular}{lccc}
\hline \multirow{2}{*}{ Activities } & \multicolumn{2}{c}{ Leptospirosis } & \multirow{2}{*}{ Total animals } \\
\cline { 2 - 4 } & Reagents & Non reagents & 235 \\
\hline Synchronized & $128(54.47 \%)$ & $107(45.53 \%)$ & 158 \\
FTET & $72(45.57 \%)^{* *}$ & $86(54.43 \%)$ & 77 \\
Protocols rejected* & $51(57.14 \%)$ & $26(33.76 \%)$ & 54 \\
Pregnancy rate & $27(50 \%)$ & $27(50 \%)$ & 11 \\
Abortion rate & $3(27.27 \%)$ & $8(72.73 \%)$ & \\
\hline
\end{tabular}

* Absence of $\mathrm{CL}, * * \mathrm{P}<0.05$.

Table 5. Frequency of embryo recipients positive for bovine viral diarrhea, and its relation to reproductive activity. Frecuencia de receptores de embriones positivos para Diarrea Viral Bovina y su relación con la actividad reproductiva.

\begin{tabular}{lccc}
\hline \multirow{2}{*}{ Activities } & \multicolumn{2}{c}{ BVD } & Total animals \\
\cline { 2 - 4 } & Reagents & Non reagents & 235 \\
\hline Synchronized & $174(74.04 \%)$ & $61(25.96 \%)$ & 158 \\
FTET & $116(73.42 \%)$ & $42(26.58 \%)$ & 77 \\
Protocols rejected $*$ & $58(75.32 \%)$ & $19(24.67 \%)$ & 54 \\
Pregnancy rate & $42(77.78 \%)$ & $12(22.22 \%)$ & 11 \\
Abortion rate & $9(81.82 \%)^{* *}$ & $2(18.18 \%)$ & \\
\hline
\end{tabular}

$*$ Absence of CL, $* * \mathrm{P}<0.05$.

Table 6. Frequency of embryo recipients positive for Infectious Bovine Rhinotracheitis (IBR), and its relation to reproductive activity. Frecuencia de receptores de embriones positivos para Rinotraqueítis Infecciosa Bovina y su relación con la actividad reproductiva.

\begin{tabular}{lccc}
\hline \multirow{2}{*}{ Activities } & \multicolumn{2}{c}{ IBR } & \multicolumn{2}{c}{ Total animals } \\
\cline { 2 - 4 } & Reagents & Non reagentes & 235 \\
\hline Synchronized & $103(43.83 \%)$ & $132(56.17)$ & 158 \\
FTET & $70(44.30 \%)$ & $88(55.70 \%)$ & 77 \\
Protocols rejected * & $33(42.85 \%)$ & $34(57.15 \%)$ & 54 \\
Pregnancy rate & $20(37.04 \%)$ & $3(27.27 \%)$ & 11 \\
Abortion rate & $8(72.73 \%)^{* *}$ & $36 \%)$ & \\
\hline
\end{tabular}

* Absence of $\mathrm{CL}, * * \mathrm{P}<0.05$. *. 
of latent infection. When performing statistical test, the rate of utilization protocols FTET presented dependent variables. Therefore, the response to the hormonal protocol depended on the recipient seropositivity at the presence of anti-N. caninum $(\mathrm{P}<0.05)$ (table 7$)$.

\section{DISCUSSION}

The ratio of transferred/processed recipients was $67.23 \%$ (158/235). This result is less than those found in similar studies concerning cattle Bos taurus $x$ B. indicus, wherein the percentages of use of the protocol ranged from $82 \%$ to 93\% (Nasser et al 2004, Looney et al 2006). Initially, this finding may have resulted from the cow synchronization without CL, and/or of the negative energy balance; facts directly related to a delay in ovulation (Beam and Butler 1998). Regarding the first aspect, all recipients received equine chorionic gonadotropin, seeking to increase ovulation rates of cows without $\mathrm{CL}$, when synchronised. This fact has been proven by other authors (Baruselli et al 2003, Cutaia et al 2003).

Likewise, recipients possessed a good energy balance, given the body condition at time of synchronisation, which was within the appropriate rating for ET protocol. Mapletoft and Pawlyshyn (1986) showed that a body condition score, between 3 and 4, is suitable for pregnancy rates of 55\% $(\mathrm{n}=633)$ and $47 \%(\mathrm{n}=175)$, respectively.

The ultrasonographic evaluation on D35 revealed a pregnancy rate of $34.2 \%$ (54/158), being consistent with similar studies in which percentages ranged from $20 \%$ to 40\% (Alder et al 2011).

On the other hand, the abortion rate was $20.37 \%$ (11/54), different to that recorded in other studies $(62.63 \%)$. However, despite being within the expected range, some losses occurred mainly between D35 and D75, a period comprising the two main stages of pregnancy: embryonic and fetal (Givens and Marley 2008). Both are stages where finding damage to the FTET program is common due to the presence of infectious agents. It is known that during the embryonic period embryonic cells are more susceptible to viruses (Wrathall and Sutmoller 1998, Bowen 1979).
Reportedly, morula and blastocyst, hatched and freed in the pellucid zone, are more susceptible to bovine herpesvirus-1 (IBR) (Vanroose et al 1997, Graham 2013), and bovine viral diarrhea BVD virus (Vanroose et al 1998, Lanyon et al 2014). Therefore, in this study, the presence of an infectious agent as a cause for some of the losses can be inferred.

After being transferred, 100\% (3/3) of Brucella abortus seropositive hosts resulted in pregnancies at D35 of gestation. However, two of them aborted before D75 of gestation. Despite the statistical significance $(\mathrm{P}<0.05)$ for pregnancy rate and abortion in cows transferred with Brucella abortus positive titers, this finding contradicts the pathophysiology of the disease. Generally, abortion related to Brucella abortus occurs during the last trimester of pregnancy, when there are high concentrations of steroid hormones and Erythritol (Samartino y Enright 1996). Therefore, this inconsistency may be caused by the influence of one of the other agents tested on this disease, or another unknown condition.

It is worth noting that seropositive recipient strains of Brucella abortus, present in herd environment, can end the pregnancy or result in birth of infected calves, which makes the infection perpetuate itself (Nicoletti 1980). In this case, the identification of these animals for disposal is necessary.

Concerning Leptospira, from the total of syncronized recipients, $54.47 \%$ (128/235) had titers against this agent. Although high, this percentage is consistent with reports made in Brazil, where seropositivity rates vary between $24.7 \%$ and $68.4 \%$ depending on the serovar (Lilenbaum and Santos 1995, Lilenbaum and Souza 2003). Also highlighted in these studies, the serovar hardjo is the most common, mainly due to its ability to adapt to the host, generating persistent infections (Givens 2006). This serovar can stay in the reproductive tract of males and females over a 12-month period (Leonard et al 1992), leading to a subclinical state to open non-lactating cows. This may explain why the selected positive recipients had no obvious clinical signs. Despite this fact, cows actively infected with a serovar ( $L$. hardjo) adapted to the host,

Table 7. Frequency of embryo recipients positive for Neospora, and its relation to reproductive activity.

Frecuencia de receptores de embriones positivos para Neospora y su relación con la actividad reproductiva.

\begin{tabular}{lccc}
\hline \multirow{2}{*}{ Activities } & \multicolumn{2}{c}{ Neosporose } & Total \\
\cline { 2 - 4 } & Reagents & Non reagentes & Total animals \\
\hline Synchronized & $150(63.82 \%)$ & $85(36.17 \%)$ & 235 \\
FTET & $93(58.86 \%)^{* *}$ & $65(41.14 \%)$ & 158 \\
Protocols rejected $*$ & $57(74.03 \%)$ & $20(25.97 \%)$ & 77 \\
Pregnancy rate & $32(59.26 \%)$ & $22(40.74 \%)$ & 54 \\
Abortion rate & $5(45.45 \%)$ & $6(54.55 \%)$ & 11 \\
\hline
\end{tabular}

*Absence of $\mathrm{CL}, * * \mathrm{P}<0.05$ 
can make serological titers $\leq 1: 100$, extending the disease vaccination (Yaeger and Holler 1997).

Regarding aborting animals related to this agent, one of the recipients had antibody titers $(1: 1600)$ against serovars hardjo and wolffi, and two of them had titles $\geq 1: 200$ against $L$. icterohaemorragiae, hardjo and wolffi serovars. This result, in the absence of vaccination, may be related to an active infection, causing abortion. Generally, during an active infection, miscarriages occur in the acute phase after weeks (Yaeger and Holler 1997). As for other recipients, the presence of different titers against Leptospira serovars suggests a high risk of abortion, and the continuous spreading of the disease (Grooms 2006).

Bovine viral diarrhea (BVD) is the most prevalent infectious disease of cattle (Lanyon et al 2014), in this work, $74.04 \%$ (174/235) of recipients presented titers, achieving a pregnancy rate of $77 \%$ (42/54) with respect to the host that were seronegative. These data are consistent with epidemiological aspects of the disease, in which a high mortality (80-100\%) stands out, compared to a low fatality (0-20\%) (Radostis and Littlejohns, 1988).

Of all BVD seropositive animals, 116 (66.6\%) were synchronized and transferred. This utilization rate of protocol was lower than expected, as reported in other studies (Nasser et al 2004, Looney et al 2006). In addition, the above is related to the action mechanism of the agent (Neill 2013). After an acute infection with BVD, a decrease in the growth of the pre-ovulatory follicle in cows has been reported (Grooms et al 1998, Bielanski et al 2013); likewise, the pre-ovulatory peak value of LH hormone is partially or completely absent from super-ovulated cows experimentally infected with the virus (McGowan et al 2003). Similarly, experimentally induced infection with this agent in heifers caused "lymphoplasmacytic oophoritis", a persistent condition occurring within 61 days of infection (Ssentongo et al 1980, Gievs and Shonda 2013).

At first US performing, 36.2\% (42/116) of seropositive and transferred recipients resulted in pregnancy status. In the second scan, nine of these receptors had no pregnancy due to abortion, which accounted for $81.82 \%$ (9/11) of all aborting animals.

When performing statistical analysis of aborting seropositive recipients, and to those seronegatives with the same condition, a significant difference $(\mathrm{P}<0.05)$ was found. These findings are consistent with the impact of BVD on reproductive performance from BVD (Virakul et al 1988, Houe and Meyling 1993), in which the pregnancy loss by infection of susceptible females can occur throughout gestation. However, these losses have higher occurrence in the first trimester of pregnancy (Sprecher et al 1991, Roeder and Cranwell 1986).

For BVD, other features should be taken into account. For example, although the serological test allows for the determination of the immune status of the animal and prior exposures to BVDV, it cannot detect persistently infected animals (PI). Thus, the existence of 174 seropositive recipients to BVDV without history of vaccination can demonstrate the exposure of animals to field virus (Lanyon et al 2014).

However, given the particularities of the technique, seronegative recipients are not necessarily free of the agent. This represents a risk for the introduction of FTET program, because some of them can be persistently infected animals (PI), and disseminators of the agent, which have the potential to infect other animals in the same herd (Grooms 2006).

This hypothesis is strengthened by having in mind the existence of scientific reports showing a high prevalence of seropositive animals, which is indicative of a high probability to find seroreactive PI animals (Lanyon et al 2014). For this reason, the use of other techniques to identify these animals becomes necessary.

In connection with BoHV-1, total seropositive animals were $43.82 \%$ (103/132). This percentage is consistent with those described by other authors in Brazil, where population titers range from $27 \%$ to $85 \%$, depending on the studied region (Alice 1978, Melo y Figueiredo 1997, Pelegrini 1993, Rocha y Leite 1995). Seropositive animals to BoHV-1 found in a herd during an investigation indicated the presence of virus carriers, a source of infection for susceptible animals, ensuring the permanence of infection (Tikoo and Babiuk 1995). In addition, this group of animals showed reproductive disturbances, characterized by early embryonic mortality, which supported the condition observed in seropositive recipients to virus. In fact, eight of the animals aborted. This result is in agreement with the negative impact on fertility of BoHV-1 that causes pathogenic effects on the CL that depends on the stage of development (Graham 2013).

Another negative consequence for the FTET program happens when incorporating seropositive animals to BoHV1 , resulting in a marked decrease in pregnancy rates. In the present work, the rate of pregnancy was $28.5 \%$ (20/70) in seroreactive animals, compared to $38.6 \%$ (34/88) in those non-seroreactives. Several epidemiological studies have investigated the impact of $\mathrm{BoHV}-1$ on reproductive performance in dairy and beef herds. Conception rates were higher in seronegative $(38.98 \%)$ than in seropositive cows $(33.33 \%)$ (Graham 2013). In another study with dairy herds comprising 9,637 animals in 65 seropositive and 38 seronegative herds, BoHV-1 was significantly related to reproductive performance with the highest risk of increased insemination index and abortions occurring in herds with a moderate seroprevalence (Raaperi et al 2012). Finally, dairy herds in Ireland found a significant association between serological evidence of exposure to BoHV-1 and reduced conception rate (Geraghty et al 2012).

Of the 235 recipients, $63.82 \%$ (150/235) were reactive to $N$. caninum, which is similar to the reported in other 
studies (Neverauskas et al 2015), seropostivity only surpassed by BVD, with $74.04 \%$. It's possible that a tropical climate, combined with a sylvatic cycle may be a major contributor to exposure and infection with $N$. caninum in this region as suggest in other research (Neverauskas et al 2015).

From the total seropositive animals, 62\% (93/150) were transferred, despite the existence of statistical significance $(\mathrm{P}<0.05)$ for this parameter. In the scientific literature, there are no reports of alterations in ovarian, endocrine, or luteal function to justify this outcome, so it may be attributed to a multifactorial relationship.

In the group of transferred reactive animals, a pregnancy rate of 34\% (32/93) was achieved. Later, during the second ultrasound, pregnancy loss was recorded in five animals. Regarding this finding, cows with serological evidence of infection had a high risk of abortion (Paré and Hietala 1997, Davison and Trees 1999), which mainly occurred during the fourth to sixth month of gestation (Anderson and Conrad 2000).

Finally, regarding $N$. caninum, serological diagnosis works well for assessing the animal exposure in the herd, and its risk of infection. Despite this condition, the diagnosis of reference is unhelpful for evaluating if abortions are due to the parasite (Anderson and Conrad 2000). Seropositive recipients to the agent, by rule, should be discarded from breeding programs (embryo transfer, artificial insemination or natural service). This is because the $N$. caninum is adapted to cattle by using vertical transmission, which helps to perpetuate the infection in the herd (Anderson and Conrad 2000).

As known, embryo transfer is a technique that involves different procedures, which must be articulated to ensure a successful outcome. The knowledge of all aspects related to embryos, infectious agents, and appropriate technics is vital for the program efficiency (Jones and Lamb 2008). Serological studies have an important role to play in highlighting the need, or otherwise, for disease control and eradication schemes. This study highlighted high levels of exposure in embryo recipients in the Acre State and suggested that the cattle industry of this region and biotechnology programs could be impacted by the negative reproductive effects of these reproductive diseases.

In this region, it is necessary to fully understand the epidemiology of these agents as well as the potential methods to control or mitigate their presence. In conclusion, to assess rates of conception, embryonic mortality and post-abortion protocol, a careful consideration of the health status of the animals should be carried out in order to reduce losses in the program.

\section{ACKNOWLEDGEMENTS}

The authors would like to thank the Universidade Estadual Paulista for its support with essential materials for this study.

\section{REFERENCES}

Adler B, M Lo, T Seemann, GL Murray. 2011. Pathogenesis of leptospirosis: the influence of genomics. Vet Microbiol 153, 73-81.

Alice JF. 1978. Isolamento do vírus da rinotraqueíte infecciosa bovina (IBR) no Brasil. Revta Bras Biol 38, 919-920.

Anderson ML, AG Andrianarivo, PA Conrad. 2000. Neosporosis in cattle. Anim Reprod Sci 60, 417-431.

Baruselli PS, MO Marques, EL Reis, JE Mello, EP Campos Filho. 2003. Taxa de concepção de diferentes protocolos de inseminação artificial em tempo fixo em vacas Bos taurus taurus x Bos taurus indicus durante o período pós-parto. Proceeding $5^{\text {th }}$ Simpósio Internacional de Reprodução Animal, Luso, Portugal, Pp 380.

Beam SW, WR Butler. 1998. Energy balance, metabolic hormones, and early postpartum follicular development in dairy cows fed prilled lipid. J Dairy Sci 81, 121-131.

Bowen RA. 1979. Viral infections of mammalian preimplantation embryos. Theriogenology 11, 5-15.

Brasil. 1995. Coordenação de Controle de Zoonoses e Animais Peçonhentos. In: Manual de Leptospirose. $2^{\text {nd }}$ ed. Ministério da Saúde, Fundação Nacional de Saúde, Brasília, DF, Brazil.

Brasil. 2006. Programa Nacional de Controle e Erradicação da Brucelose e da Tuberculose Animal (PNCEBT). Ministério da Agricultura, Pecuária e Abastecimento (MAPA/SDA/DAS), Brasília, DF, Brazil.

Corrêa SR, P Andrade, K Euclides Filho, RGO Alves. 2000. Avaliação de um sistema de produção de gado de corte. 1. Desempenho reprodutivo. Revta Bras Zootec 29, 2209-2215.

Cutaia L, R Tríbulo, D Moreno, GA Bó. 2003. Pregnancy rates in lactating beef cows treated with progesterone releasing devices, estradiol benzoate and equine chorionic gonadotropin (eCG). Theriogenology 59, 216.

Davison HC, A Otter, AJ Trees.1999. Significance of Neospora caninum in British dairy cattle determined by estimation of seroprevalence in normally calving cattle and aborting cattle. Int J Parasitol 29, 1189-1194.

Del Fava C, EM Pituco, ME Genovez. 2007. Diagnóstico diferencial de doenças da reprodução em bovinos: experiência do Instituto Biológico. Biológico 69,73-79.

Desvars A, E Cardinale, A Michault. 2011. Animal leptospirosis in small tropical areas. Epidemiol Infect 139, 167-188.

Dubovi J. 2013. Laboratory diagnosis of bovine viral diarrhea virus. Biologicals 41, 8-13.

Faine S. 1999. Leptospira and leptospirosis. $2^{\text {nd }}$ ed. MedSci, Melbourne, Australia.

Ferreira AM, CAA Torres. 1993. Perda de peso corporal e cessação da atividade ovariana luteínica cíclica em vacas mestiças leiteiras. Pesq Agropec Bras 28, 411-418.

Geraghty T, L O'Grady. 2012. Effect of exposure to bovine herpes virus 1 on conception rate: a multivariate analysis. Proceedings of $27^{\text {th }}$ World Buiatrics Congress, Lisbon, Portugal, Pp 205-206.

Givens MD. 2006. A clinical, evidence-based approach to infectious causes of infertility in beef cattle. Theriogenology 66, 648-654.

Givens MD, MSD Marley. 2008. Infectious causes of embryonic and fetal mortality. Theriogenology 70, 270-285.

Graham 2013. Bovine herpes virus-1 (BoHV-1) in cattle-a review with emphasis on reproductive impacts and the emergence of infection in Ireland and the United Kingdom. Irish Vet J 66, 15.

Grooms DL, KV Brock, JL Pate, ML Day. 1998. Changes in ovarian follicles following acute infection with bovine viral diarrhea virus. Theriogenology 49, 595-605.

Grooms DL. 2006. Reproductive losses caused by bovine viral diarrhea virus and leptospirosis. Theriogenology 66, 624-628.

Houe H, K Myrup-Pedersen, A Meyling. 1993. The effect of bovine virus diarrhea virus infection on conception rate. Prev Vet Med 15, 117-123.

Jones AL, GC Lamb. 2008. Nutrition, synchronization, and management of beef embryo transfer recipients. Theriogenology 69 , 107-115. 
Lanyon SR, FI Hill, MP Reichel, J Brownlie. 2014. Bovine viral diarrhoea: pathogenesis and diagnosis. Vet $J$ 199, 201-209.

Leonard FC, PJ Quinn, WA Ellis, K O'Farrell. 1992. Duration of urinary excretion of leptospires by cattle naturally or experimentally infected with Leptospira interrogans serovar Hardjo. Vet Rec 131, 435-439.

Lilenbaum W, MRC Santos. 1995. Leptospirosis on animal reproduction. III. The role of serovar hardjo on bovine leptospirosis in Rio de Janeiro, Brazil. Rev Latinoam Microbiol 37, 87-92.

Lilenbaum W, GN Souza. 2003. Factors associated with bovine leptospirosis in Rio de Janeiro, Brazil. Res Vet Sci 75, 249-251.

Looney CR, JS Nelson, HJ Schneider, DW Forrest. 2006. Improving fertility in beef cow recipients. Theriogenology 65, 201-209.

MacMillan A. 1990. Conventional serological tests. In: Nielsen K, Duncan JR (eds). Animal Brucellosis. CRC Press Inc., Boca Raton, Florida, USA, Pp 153-197.

Magalhães MN, ACP Lima. 2000. Noções de Probabilidade e Estatística. $2^{\text {nd }}$ ed. IME-USP, São Paulo, Brasil.

Mapletoft RJ, CE Lindsell, V Pawlyshyn. 1986. Effects of clenbuterol, body condition and non-surgical embryo transfer equipment on pregnancy rates in bovine recipients. Theriogenology 25, 172.

McGowan MR, M Kafi, PD Kirkland, R Kelly, H Bielefeldt-Ohmann, MD Occhio, D Jillella. 2003. Studies of the pathogenesis of bovine pestivirus-induced ovarian dysfunction in superovulated dairy cattle. Theriogenology 59, 1051-1066.

Melo CB, AM Oliveira, HCP Figueiredo, RC Leite, ZIP Lobato. 1997. Prevalência de anticorpos contra herpesvírus bovino 1, vírus da diarréia bovina a vírus e vírus da leucose enzoótica bovina em bovinos do Estado de Sergipe, Brasil. Revta Bras Reprod Anim 21, 160-161.

Nasser LF, EL Reis, MA Oliveira, GA Bó, PS Baruselli. 2004. Comparison of four synchronization protocols for fixed-time bovine embryo transfer in Bos indicus x Bos taurus recipients. Theriogenology 62, 1577-1584.

Neill JD. 2013 Molecular biology of bovine viral diarrhea virus. Biologicals 41, 2-7.

Neverauskas CE, A Nasir, MP Reichel. 2015. Prevalence and distribution of Neospora caninum in water buffalo (Bubalus bubalis) and cattle in the Northern Territory of Australia. Parasitol Int 64, 392-396.

Nicoletti P. 1980. The epidemiology of bovine brucellosis. Adv Vet Sci Comp Med 24, 69-95.

Okano W, APL Bracarense, ACF Reis, AA Alfieri. 2003. Achados histopatológicos em fetos bovinos abortados e não abortados. Arq Bras Med Vet Zootec 55, 223-225.

Paré J, MC Thurmond, SK Hietala. 1997. Neospora caninum antibodies in cows during pregnancy as a predictor of congenital infection and abortion. J Parasitol 83, 82-87.

Pelegrini AO. 1993. Detecção de anticorpos para herpesvírus bovino tipo 1, vírus da diarréia bovina a vírus (BVD) e vírus da língua azul em um período de três anos em gado de corte no Pantanal Matogrossense, MS. Revta Bras Reprod Anim 18, 112-115.

Raaperi K, S Bougeard, A Aleksejev, T Orro, A Vitrop. 2012. Association of herd BHV-1 seroprevalence with respiratory disease in young stock in Estonian dairy cattle. Res Vet Sci 93,641-648.
Radostits OM, IR Littlejohns. 1988. New concepts in the pathogenesis, diagnosis and control of disease caused by the bovine viral diarrhea virus. Can Vet J 29, 513-528.

Rocha MA, AMG Gouveia, RC Leite. 1995. Detecção de anticorpos HVB1 em touros de uma central de sêmen - soroneutralização e isolamento no sêmen. Revt Bras Reprod Anim 19, 181-186.

Roeder P, M Jeffrey, M Cranwell. 1986. Pestivirus fetopathogenicity in cattle: changing sequella with fetal maturation. Vet Rec 118, 44-48.

Royal M, GE Mann, PE Flint. 2000. Strategies for reversing the trend towards subfertility in dairy cattle. Vet $J$ 160, 53-60.

Samartino LE, FM Enright. 1996. Brucella abortus differs in the multiplication within bovine chorioallantoic membrane explants from early and late gestation. Comp Immunol Microbiol 19, 55-63.

Sayers RG, N Byrne, E O’Doherty, S Arkins. 2015. Prevalence of exposure to bovine viral diarrhoea virus (BVDV) and bovine herpesvirus-1 (BoHV-1) in Irish dairy herds. Res Vet Sci 100, 21-30.

Seleem MN, SM Boyle. 2010. Sriranganathan N: Brucellosis: a reemerging zoonosis. Vet Microbiol 140, 392-398.

Sprecher D, J Baker, R Holland, B Yamini. 1991. An outbreak of fetal and neonatal losses associated with the diagnosis of bovine viral diarrhea virus in a dairy herd. Theriogenology 36, 567-606.

Ssentongo YK, RH Johnson, JR Smith. 1980. Association of bovine viral diarrhoea mucosal disease virus with ovaritis in cattle. Aust Vet J 56, 272-273.

Sutherland SS, J Searson. 1990. The immune response to Brucella abortus: the humoral immune response. In: Nielsen K, Duncan JR (eds), Animal Brucellosis. CRC Press, Inc., Boca Raton, Florida, USA, Pp 65-81.

Takiuchi E, KC Médici, AF Alfieri, AA Alfieri. 2005. Bovine herpesvirus type 1 abortions detected by a semi nested-PCR in Brazilian cattle herds. Res Vet Sci 79, 85-88.

Tikoo SK, M Campos, LA Babiuk. 1995. Bovine herpesvirus 1 (BHV1): biology, pathogenesis, and control. Adv Virus Res 45, 91-223.

Vanroose G, H Nauwynck, A Van Soom, E Vanopdenbosch, A De Kruif. 1997. Susceptibility of zona-intact and zona-free in vitro produced bovine embryos at different stages of development to an infection with bovine herpesvirus-1. Theriogenology 47, 1389-1402.

Vanroose G, H Nauwynck, A Van Soom, E Vanopdenbosch, A De Kruif. 1998. Replication of cytopathic and noncytopathic bovine viral diarrhea virus in zona-free and zona-intact in vitro produced bovine embryos and the effect on embryo quality. Biol Reprod 58, 857-866.

Vanroose G, A Kruif, A Van Soom. 2000. Embryonic mortality and embryo-pathogen interactions. Anim Reprod Sci 60, 131-143.

Virakul P, M Fahning, H Joo, R Zemjanis. 1988. Fertility of cows challenged with a cytopathic strain of bovine viral diarrhea virus during an outbreak of spontaneous infection with a noncytopathic strain. Theriogenology 29, 441-449.

Wrathall AE, P Sutmoller. 1998. Potential of embryo transfer to control transmission of disease. In: Stringfellow DA, Seidel SM (eds). Manual of the International Embryo Transfer Society. IETS, Savoy IL, USA, Pp 17-44.

Yaeger M, LD Holler. 1997. Bacterial causes of bovine infertility and abortion. In: Youngquist RS (ed). Current Therapy in Large Animal Theriogenology. W.B. Saunders, Philadelphia, USA, Pp 364-372. 